Mohr has now re-examined his data for the phytochrome regulated synthesis of anthocyanin and ascorbic acid in the white mustard seedling, using sequential irradiations with red and far-red light. Briefly, red light promotes the formation of the apparently active form of the phytochrome molecule, PFr, and thereby initiates biochemical synthesis. Far-red light, however, abolishes this response by converting PFR back to the inactive form of the molecule PR. In continuous far-red light, however, enough phytochrome is converted to PFR to initiate and maintain the synthesis of anthocyanin and ascorbic acid. This property of the phytochrome molecule makes it possible to perform some pretty tricks with red and far-red light. The way the plant reacts to these colours of light given in different amounts and in different sequences makes it possible to gain some insight into what the phytochrome molecule is doing in the cell.

Mohr and his colleagues show that in continuous far-red light, PFR exists in an, as yet, unexplained "excited" state, which promotes the formation of both anthocyanin and ascorbic acid. With the passing of time, however, it becomes clear that this "excited" state is not the same for the two synthetic systems. After twelve hours of continuous far-red light, red light greatly promotes the synthesis of anthocyanin, but is completely ineffective in promoting further synthesis of ascorbic acid. What Mohr deduces from these results is that the PFR formed under far-red light takes part in different kinds of primary reactions in promoting synthesis of the two compounds. In one case the molecule is still susceptible to further conversion by red light, but in the other the active molecules have become in some way immune to further photoconversion.

Important and unequivocal as this conclusion is, there will inevitably be much head shaking and anguish in the photomorphogenesis camp. The attempt to isolate one primary reaction for phytochrome has proved challenge enough; what hope is there of identifying similar involvements? There is not much hope at present, perhaps, but at least Mohr's conclusions should make it rather simpler to explain those paradoxical experimental results where the behaviour of phytochrome as observed in the difference meter seems to bear no relation at all to the physiological responses of the nlant.

EXPLORATION

\section{Sacrifice for Plants}

by our Botany Correspondent

WHATEVER may be said about the boredom of botany, its exponents used to be among the most reckless of adventurers, facing disease and danger in the search for new knowledge. Among the most intrepid of plant hunters were Sir Joseph Banks and Daniel Solander who sailed to Australia two hundred years ago with Captain James Cook on his ship Endeavour. The plants which they collected on this voyage became the basis of the department of botany of the British Museum (Natural History) where they are still in constant use. Banks's great contribution to botanical knowledge was recalled on February 23 by Dr W. T. Stearn when he gave the second of six weekly lectures about the Natural History Museum, which have been sponsored by the museum and the Victorian Society.

Banks, a rich landowner who had been to Eton, Harrow and Oxford, showed sufficient promise as a botanist to be elected a Fellow of the Royal Society at the age of 23. Deciding that a trip to the South Seas would provide a good opportunity for a grand tour of the world, he persuaded the society to let him go with Cook on his voyage to observe the transit of Venus. Banks also enlisted the Swede Daniel Solander, an extremely erudite pupil of Linnaeus, and Sydney Parkinson, the artist who died during the voyage.

The first important collections of the voyage were made during secret midnight excursions at Rio de Janeiro, where the Portuguese viceroy would not let Cook and his men ashore. In Tahiti, where the welcome was much more friendly, they found a rich vegetation, especially orchids, but Banks was most impressed by the breadfruit plant. From Tahiti, where the transit of Venus was duly observed, the expedition moved south, and, not finding the great southern continent which some people had imagined to be there, pressed on to New Zealand. Here a large collection of specimens was assembled, including the shrubby veronica, Hebe. Banks's foresight in taking along a Tahitian priest who could act as interpreter enabled the explorers to make friendly contact with the Maoris, who had attacked their previous European visitor Abel Tasman.

Endeavour then proceeded to Australia, known then as New Holland, the west side having been explored by the Dutch. Cook and his comrades found an inlet on the eastern coast which the captain would have called Sting Ray Bay, but which was so rich in floral delights that it was named Botany Bay. Acacia and the shrub which was later to be called Banksia were two of the many plants they found there. After leaving Botany Bay, Endeavour struck a coral reef and had to put into a nearhv river inlet for renairs.
At the end of six weeks when the work was complete, the botanists had become familiar with every aspect of the surrounding flora and fauna. They saw a kangaroo, which was then unknown in Europe, and was to be classified by a German scholar as a new species of mouse, Mus kangaroo. Dr Stearn visited this part of Queensland last year, and found its vegetation virtually unchanged from the descriptions of Banks and Solander. He advocates that this region around Cooktown should become a new national park.

After many privations, particularly in disease ridden Java, where Parkinson and other crew members died, the survivors arrived home, and Banks established his home in London as a scientific centre. Sadly, the book he had planned as a record of the voyage, to be illustrated by Parkinson's drawings, was never finished. But his collections passed to his colleague Robert Brown, an army surgeon turned botanist, who added to them during his own travels. Brown, whom Dr Stearn described as the greatest botanist Britain has produced, went on the next British voyage to Australia, which was led by Flinders. He was accompanied by the Viennese artist Ferdinand Bauer, and they brought back a wealth of specimens and drawings. At the same time, Bauer's brother Franz settled at Kew, where a collection was growing up to rival that started by Banks, Brown gave his collections to the British Museum and became the first keeper of the department of botany, from which was to grow the separate Natural History Museum.

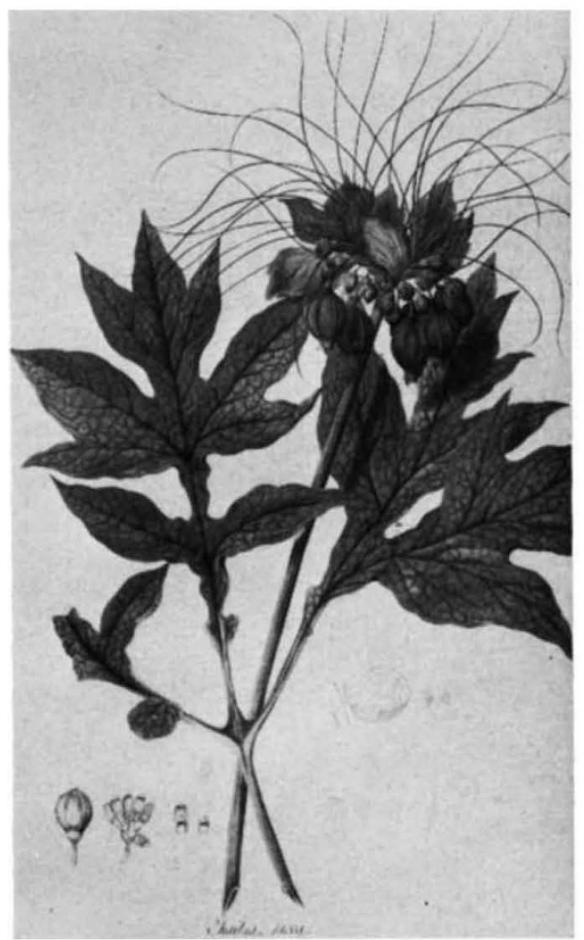

Chaitaea tacca (Tacca leontopetaloides) collected from Tahiti and drawn by Parkinson in 1769. The drawing is now in the department of botany of the Rritish Museum (Natural Historv). 